\title{
HUBUNGAN FINANCIAL DEEPENING DAN PERTUMBUHAN EKONOMI: Studi Empiris Di Indonesia
}

\author{
Jihad Lukis Panjawa \\ Universitas Sebelas Maret Surakarta, Indonesia \\ Jihadpanjawa@gmail.com \\ Ira Fitriani Widianingrum \\ Universitas Sebelas Maret Surakarta, Indonesia \\ irafitrianiwidianingrum@gmail.com
}

\begin{abstract}
Financial deepening has been identified as one of the strategies which can accelerate the rate of development. Deepening the financial sector is one important step in the effort to develop the country's financial markets especially developing countries one of which Indonesia. In this research will identify is the relationship between finacial deepening, the exchange rate of rupiah, interest rates and economic growth in Indonesia year of 1985-2015. The approach used in this study is the causality granger. The results in this study was the performance of the financial sector is still shallow. Financial deepening and economic growth have a oneway relationship, namely economic growth affects the financial deepening. Evidence that the introduction of Demand-Following Hypothesis in Indonesia. The exchange rate of the rupiah and financial deepening do not influence each other, as well as economic growth and the exchange rate of the rupiah not influence each other.
\end{abstract}

Key words: Financial Deepening, Economic Growth, Rate of Rupiah Exchange, Causality. 


\begin{abstract}
Abstrak
Financial Deepening telah diidentifikasi sebagai salah satu strategi yang dapat mempercepat laju pembangunan. Memperdalam sektor keuangan merupakan salah satu langkah penting dalam upaya mengembangkan pasar keuangan negara terutama negara berkembang salab satunya Indonesia. Dalam penelitian ini yang akan diidentifikasi adalah bubungan antara financial deepening, nilai tukar rupiah, suku bunga dan pertumbuban ekonomi di Indonesia tahun 1985-2015. Pendekatan yang digunakan dalam penelitian ini adalah kausal kausalitas. Hasil dalam penelitian ini adalah kinerja sektor kenangan yang masih dangkal. Pendalaman keuangan dan pertumbuban ekonomi memiliki hubungan satu arah, yaitu pertumbuban ekonomi mempengarubi pendalaman keuangan. Bukti bahwa pengenalan Demand-Following Hypothesis di Indonesia. Nilai tukar rupiah dan financial deepening tidak mempengarubi satu sama lain, serta pertumbuban ekonomi dan nilai tukar rupiah tidak saling mempengarubi.
\end{abstract}

Kata Kunci: Financial Deepening, Pertumbuhan Ekonomi, Nilai Tukar Rupiah, Kausalitas.

\title{
A. Pendahuluan
}

Sektor keuangan sangat berperan penting dalam meningkatkan pertumbuhan ekonomi. Financial deepening telah diidentifikasi sebagai salah satu strategi yang pelaksanaannya dapat mempercepat laju pembangunan. Namun, efek dari strategi ini perlu ditentukan dan diperiksa dari waktu ke waktu terutama bagi negara berkembang. ${ }^{1}$ Indonesia sebagai negara berkembang memiliki karakter yang tidak jauh berbeda dengan negara berkembang lainnya. Tujuan pencapaian tingkat pertumbuhan ekonomi yang tinggi dalam proses pembangunannya dihadapkan pada permasalahan dalam keterbatasan modal untuk membiayai investasi pembangunan. Berbagai upaya telah dilakukan guna meningkatkan peran sektor keuangan dalam pembiayaan

1 Onwumere, J, The Impact of Financial Deepening on Economic Growth: Evidence form Nigeria, Research Journal of Finance and Accounting, Vol. 3 No.10. 2012, hlm 64-71. 
pembangunan secara mandiri dan tidak tergantung dari bantuan luar negeri. ${ }^{2}$

Lembaga keuangan mempunyai peran penting dalam pembentukan jumlah uang beredar sebagai sumber dana pembangunan. Semakin besar jumlah uang beredar akan mendorong dan meningkatkan financial deepening, yaitu penghimpunan dana pembangunan yang bersumber dari sektor keuangan. ${ }^{3}$ Bank Indonesia melaporkan bahwa sektor keuangan Indonesia masih dapat dianggap dangkal (shallow) dibanding beberapa negara utama di kawasan Asia. Dangkalnya sektor keuangan Indonesia tercermin pada beberapa indikator. Perkembangan rasio M2/GDP, sebagai salah satu indikator kedalaman sektor keuangan. ${ }^{4}$ Berikut grafik perkembangan financial deepening beberapa negara Asia.

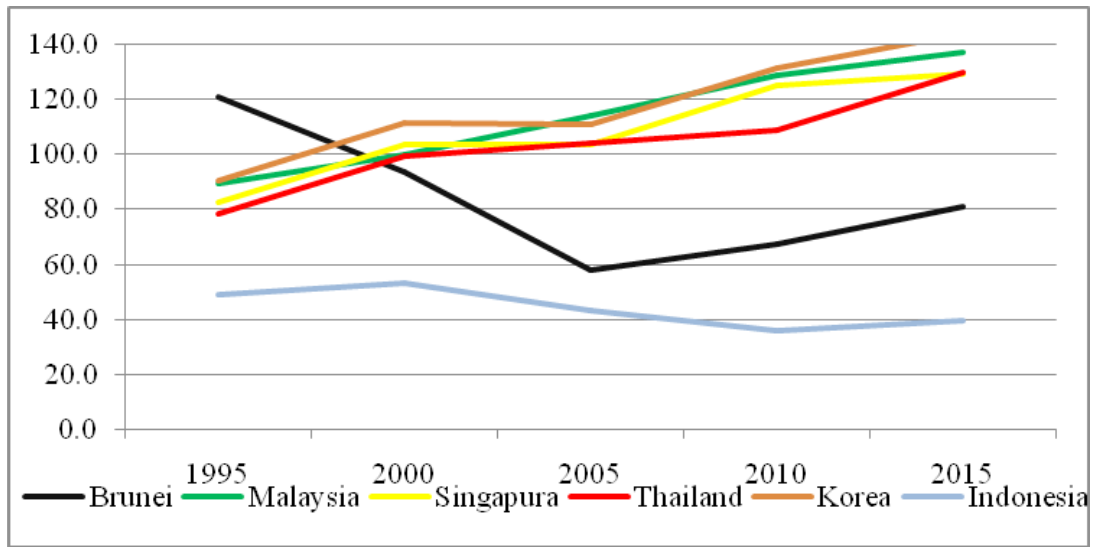

Grafik 1. Perkembangan Financial Deepening Beberapa Negara Asia Sumber: (Asian Development Bank, Various years)

Bank Indonesia juga menyampaikan bahwa kedangkalan sektor keuangan Indonesia ini disebabkan oleh terbatasnya

2 Ruslan. D, "Analisis Financial Deepening di Indonesia", Journal of Indonesian Applied Economics, Vol. 5 No. 2, 2011, hlm 183-204.

3 Pulungan, A. M, "Perkembangan Perbankan dan Problem Intermediasi", Jurnal Keuangan dan Perbankan, Vol. 16 No. 2, 2012, hlm 286-303.

${ }^{4}$ Bank Indonesia, Laporan Perekonomian Indonesia, (2009), Dipetik Mei 14, 2018, dari http://www.bi.go.id/id/publikasi/laporan-tahunan/perekonomian/ Pages/lpi_09.aspx 
alternatif investasi dan pembiayaan, fasilitas untuk lindung nilai (bedging), serta fasilitas mengurangi risiko (asuransi). Pendalaman sektor keuangan merupakan salah satu langkah penting dalam upaya mengembangkan pasar keuangan suatu negara. ${ }^{5}$ Berikut grafik perkembangan financial deepening di Indonesia tahun 1987- 2015.

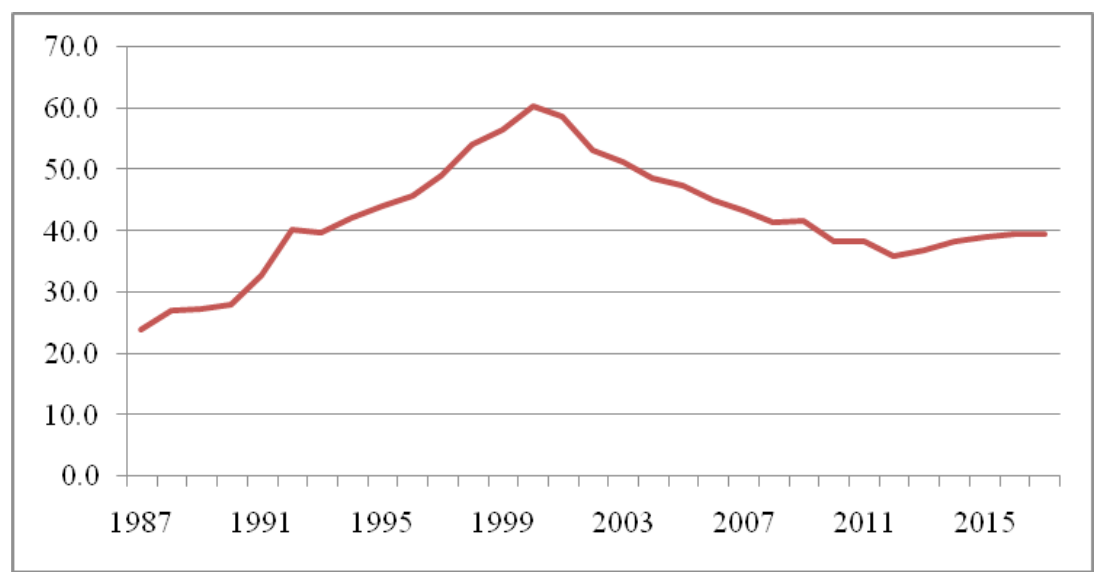

Grafik 2. Perkembangan Financial Deepening di Indonesia

Sumber: (Asian Development Bank, Various years)

Berdasarkan grafik 2. menunjukkan bahwa rasio kedalaman sektor keuangan Indonesia pada tahun 1987 sebesar 27,1 persen, mengalami peneningkatan pada tahun 1997 menjadi sebesar 56,7 persen. Sejak krisis tahun 1997/1998 kedalaman sektor keuangan (financial deeeping) terus menunjukkan penurunan. Pada tahun 2007 rasio kedalaman sektor keuangan turun menjadi 41,8 persen. Munculnya krisis keuangan global tahun 2008 juga cukup berdampak pada menurunnya sektor keuangan.

Fakta yang telah disajikan oleh Bank Indonesia (2009) menunjukkan bahwa (1) adanya gejolak perekonomian dalam negeri maupun global akan berdampak pada sektor keuangan di Indonesia (2) rasio M2/GDP di Indonesia masih tergolong rendah yaitu sekitar 40 persen ( $<50$ persen). Peran sektor keuangan

\section{${ }^{5}$ Ibid.}


dalam mendorong pertumbuhan ekonomi akan bergantung pada bagaimana perkembangan sektor keuangan di Indonesia. Terkait dengan hal ini, Indonesia perlu berupaya lebih banyak untuk mengejar ketertinggalan dari negara-negara berkembang lainnya dalam hal mengembangkan sektor keuangan. Oleh karena itu, menarik untuk menganalisis hubungan antara financial deepening, nilai tukar rupiah dan pertumbuhan ekonomi di Indonesia.

Sektor perbankan yang kompetitif dan berkembang dengan baik mampu berkontribusi dalam pertumbuhan ekonomi. Sektor perbankan harus mampu memobilisai, menggabungkan dan menyalurkan tabungan domestik menjadi modal produktif serta memberikan kontribusi terhadap pertumbuhan ekonomi. Sektor perbankan yang kompetitif ditunjukkan dengan tingkat pinjaman yang tinggi dan suku bunga kredit yang rendah sehingga akan mentransformasikan tabungan rumah tangga menjadi modal investasi produktif yang lebih cepat. Dalam hal ini, pertumbuhan ekonomi meningkatkan permintaan untuk instrumen keuangan yang canggih sehingga pada gilirannya akan menyebabkan pertumbuhan di sektor keuangan. ${ }^{6}$

Menurut Robinson (dalam Aye, 2015) secara teoritis, terdapat beberapa hipotesis hubungan antara keuangan dan pertumbuhan ekonomi. (1) Supply-leading bypothesis menunjukkan bahwa financial deepening memacu pertumbuhan. Keberadaan dan perkembangan pasar keuangan membawa tingkat yang lebih tinggi dari tabungan dan investasi dan meningkatkan efisiensi akumulasi modal. Hipotesis ini berpendapat bahwa yang lembaga keuangan yang berfungsi dengan baik dapat meningkatkan efisiensi ekonomi secara keseluruhan, menciptakan dan memperluas likuiditas, memobilisasi tabungan, meningkatkan akumulasi modal mentransfer sumber daya dari sektor tradisional (non-pertumbuhan) guna merangasang pertumbuhan sektor modern lainnya, dan

${ }^{6}$ Ohwofasa, B. O.-C.. "Financial Deepening and Economic Growth in Nigeria”, 1986-2011: An Empirical Investigation. Vol 1, No. 1, Tahun 2013, hlm. 2442. 
juga mempromosikan kompeten tanggapan pengusaha di sektor ekonomi modern. (2) Demand-following Hyphothesis menjelaskan bahwa perkembangan pasar keuangan hanyalah respon lain untuk pertumbuhan ekonomi (pertumbuhan menghasilkan permintaan untuk produk-produk keuangan). Ini berarti bahwa setiap upaya awal untuk mengembangkan pasar keuangan dapat mengakibatkan pemborosan sumber daya yang dapat dialokasikan untuk keperluan yang lebih berguna pada tahap awal pertumbuhan. Sebagai kemajuan ekonomi, tahap awal pertumbuhan ini akan memicu meningkatnya permintaan layanan keuangan yang lebih dan dengan demikian menyebabkan pengembangan keuangan yang lebih besar. Pertumbuhan ekonomi merupakan faktor penyebab untuk pengembangan keuangan. Apabila sektor riil tumbuh, maka akan meningkat permintaan untuk jasa keuangan sehingga merangsang sektor keuangan.

Marashdeh (2014) melakukan studi empiris mengenai hubungan antara financial deepening dan pertumbuhan ekonomi Hasil penelitian menunjukkan mendukung hipotesis supply-leading yang financial deepening memacu pertumbuhan ekonomi. Selain itu, studi yang dilakukan oleh Yildiz (2015) menyimpulkan bahwa berlakunya hipotesis demand-pulling dalam suatu perekonomi apabila sektor riil tumbuh dan akan meningkat permintaan untuk jasa keuangan sehingga merangsang sektor keuangan.

Tingkat financial deepening mencerminkan tingkat kesehatan sektor keuangan berkaitan kemampuan kredit dengan suku bunga kredit dan deposito. Teori financial deepening mendefinisikan peran positif dari sistem keuangan pada pertumbuhan ekonomi dengan ukuran aktivitas sektor. Artinya, aktivitas sektor ekonomi yang tinggi sebagai perantara diasumsikan mampu untuk menghasilkan alokasi yang efisien. Dalam studi pembangunan, financial deepening sangat sering mengacu pada peningkatan penyediaan layanan keuangan dengan pilihan layanan yang lebih luas diarahkan untuk pengembangan semua lapisan masyarakat. Ukuran sektor keuangan biasanya diukur dengan dua indikator kuantitatif dasar, yaitu rasio 
monetisasi dan rasio intermediasi. Rasio monetisasi mencakup uang sebagai indikator dasar (liquid liabilities) seperti uang beredar luas terhadap GDP. Rasio intermediasi terdiri dari indikator mengenai langkah-langkah berbasis bank seperti kredit perbankan untuk tindakan berbasis sektor swasta dan modal swasta seperti rasio kapitalisasi pasar saham. ${ }^{7}$

Nilai tukar mata uang pada dasarnya dipengaruhi oleh banyak faktor sesuai dengan sistem yang dianutnya dan fluktuasi nilai tukar mata uang akan berdampak pada perekonomian. Apresiasi mata uang domestik terhadap mata uang asing dapat menyebabakan semakin meningkatnya permintaan masyarakat akan barang dan jasa. Apabila terjadi keadaan over demand, maka dapat mengakibatkan inflasi yang tinggi. Sedangkan apabila terjadi depresiasi mata uang uang domestik terhadap mata uang asing, maka dapat mengakibatkan masyarakat akan terus memburu mata uang asing. Kondisi ini dikarenakan masyarakat akan menyimpan sebagian kekayaan dalam bentuk mata uang asing. Sehingga secara umum depresiasi nilai tukar mata uang akan berdampak negatif terhadap financial deepening. ${ }^{8}$ Financial deepening lebih efektif digunakan untuk menstabilkan fluktuasi nilai tukar karena pengaruh investasi pada output nasional dan ekspor. ${ }^{9}$

Selain itu, financial deepening memainkan peran dalam memberikan kontribusi investasi asing langsung dan pertumbuhan ekonomi, baik secara langsung maupun tidak langsung. Hal ini menunjukkan bahwa perlu adanya kebutuhan mereformasi sistem keuangan untuk membawa lebih banyak investasi asing langsung dan pertumbuhan ekonomi dalam perekonomian suatu negara. ${ }^{10}$

${ }^{7}$ Ndebbio, J. Financial Deepening, "Economic Growth and Development: Evidence from Selected Sub-Saharan African Countries", African Economic Research Consortium, Research Paper Vol. 142, Agustus 2004, hlm. 1-24.

${ }^{8}$ Ruslan, ibid.

9 Aulia. M. D, "Analisis Efektivitas Penggunaan Cadangan Devisa dan Financial Deepening Terhadap Stabilitas Nilai Tukar", Jurnal Ekonomi dan Kebijakan Publik, Vol.3 No.2,Tahun 2016, hlm. 78-92.

${ }^{10}$ Pradhan, R. P. "Financial Deepening, Foreign Direct Investment and Economic Growth: Are They Cointegerated", International Journal of Financial Research, Vol. 1, No. 1, Tahun 2010. 37-43. 
Studi empiri menemukan bahwa kecepatan jumlah uang beredar dan likuiditas pasar meningkatkan pertumbuhan ekonomi. ${ }^{11}$ Pemerintah harus mengambil upaya untuk meningkatkan financial deepening, sehingga meningkatkan pertumbuhan ekonomi. ${ }^{12}$ Upaya khusus harus dimasukkan untuk memberikan kredit mudah untuk sektor swasta, pengembangan pasar modal dan juga untuk mendorong perdagangan luar negeri. Hasil empiris lain juga menunjukkan financial deepening dan pertumbuhan ekonomi tidak akan memiliki hubungan sebab akibat yang kuat apabila mengabaikan sektor riil. ${ }^{13}$

Berdasarkan penjelasan mengenai hipotesis hubungan antara keuangan dan pertumbuhan ekonomi yang perlu dibuktikan, serta penelitain terdahulu yang masih belum mampu menjelaskan secara sepesifik dikarenakan kondisi maupun fenomena pembangunan negara yang berbeda dan perlu pengamatan lebih jauh, Oleh karena itu, dapat diambil rumusan masalah bagaimana keterkaitan hubungan financial deepening, atau nilai tukar dan pertumbuhan ekonomi di Indonesia.?

Jenis data yang digunakan adalah data sekunder yang diperoleh dari Bank Indonesia dan Asian Development Bank. Studi ini menggunakan data runtut waktu (time series). Data runtut waktu (time series) adalah sekumpulan observasi terhadap nilai-nilai sebuah variabel dari beberapa periode waktu yang berbeda. Data time series harus terpenuhinya asumsi dasar yaitu kestasioneritasan (stationary). ${ }^{14}$ Data yang digunakan adalah tahunan dari 19852015 di Indonesia. Variabel yang digunakan dalam penelitian ini adalah rasio jumlah uang beredar terhadap GDP nominal (financial deepening) yang dinotasikan dengan FD, nilai tukar rupiah rupiah

11 Onwumere, J. Ibid.

12 Ghildiyal, V. A. "Impact of Financial Deepening on Economic Growth in Indian Perspective: ADRL bound Testing Appoac to Cointegration", Asian Economic and Social Society, Vol 3. No. 3, Tahun 2015, hlm. 49-60.

13 Aye, G. C. "Causality between Financial Deepening and Economic Growth in Negeria: Evidence form a Bootstrap Rolling Window Approach", Journal of Economic, Business and Management, Vol3, No. 8, Tahun 2015. hlm. 795-801.

${ }^{14}$ Gujarati, N. D. Basic Econometrics (4rd Edition ed.). (New York: McGrawHill, 2004) 
yang dinotasikan dengan EXCR dan pertumbuhan ekonomi yang dinotasikan dengan EG. Alat analisis yang digunakan dalan penelitian ini kausalitas granger.

\section{a. Uji Stasioneritas}

Suatu data urut waktu dikatakan stasioner apabila ratarata, varian dan otokovarian pada berbagai waktu kelambanan (lag) bernilai konstan pada titik waktu yang manapun pengukuran dilakukan. Data urut waktu yang tidak stationer sering disebut sebagai data urut waktu yang memiliki rata-rata berubah seiring waktu (time varying mean) atau variasi berubah seiring waktu (time varying variance) atau keduanya. Jika data urut waktu tidak stationer, maka perilakunya terbatas pada periode waktu yang spesifik saja. Karenanya, tidak mungkin menggeneralisir perilaku tersebut untuk periode-periode waktu yang lainnya. Uji stationer data dengan menggunakan Uji Dickey Fuller, dimulai dari sebuah proses autoregresi orde pertama untuk tiap-tiap variabell pada tingkat level. Jika menunjukan hasil data stationer, maka dapat dilanjukan ke uji berikunya. Namun jika data ternyata tidak stationer pada estimasi pertama maka data tersebut harus diubah dahulu kedalam bentuk diferensialnya. ${ }^{15}$ Berikut bentuk dasar uji stasioneritas.

\section{Dickey Fuller (DF)}

$$
\begin{aligned}
& \Delta Y_{t}=\delta Y_{t-1}+\varepsilon_{t} \\
& \Delta Y_{t}=\beta_{1}+\delta Y_{t-1}+\varepsilon_{t} \\
& \Delta Y_{t}=\beta_{1}+\beta_{2} t+\delta Y_{t-1}+\varepsilon_{t}
\end{aligned}
$$

\section{Augmented Dickey Fuller (ADF)}

$$
\begin{aligned}
& \Delta Y_{t}=\delta Y_{t-1}+\sum_{i=1}^{k} \alpha_{i} \Delta Y_{t-i}+\varepsilon_{t} \\
& \Delta Y_{t}=\beta_{1}+\delta Y_{t-1}+\sum_{i=1}^{k} \alpha_{i} \Delta Y_{t-i}+\varepsilon_{t} \\
& \Delta Y_{t}=\beta_{1}+\beta_{2} t+\delta Y_{t-1}+\sum_{i=1}^{k} \alpha_{i} \Delta Y_{t-i}+\varepsilon_{t}
\end{aligned}
$$

Model uji DF dan ADF terbaik adalah model yang memiliki nilai Akaike information criterion (AIC) minimum. Apabila koefisien $\delta>0$ (positif), maka uji DF dan ADF tidak valid dikarenakan data

$$
{ }^{15} \text { Ibid. }
$$


urut waktu yang diuji berarti bersifat eksplosif (Gujarati, 2010). Hipotesis uji DF dan ADF adalah: $\mathrm{H}_{0}: \delta=0$ (data tidak stasioner) dengan $\mathrm{H}_{\mathrm{A}}: \delta<0$ (data stasioner). Apabila prob.t $>$ tingkat signifikansi alfa maka menerima null hypothesis.

\section{b. Uji Kointegrasi}

Kointegrasi hanya terjadi di antara variabel-variabel yang tidak stasioner. Kointegrasi terjadi apabila kombinasi di antara variabel-variabel yang tidak stasioner, saling menghilangkan penyebab ketidakstasioneran masing-masing variabel. Secara ekonomi, dua atau lebih variabel berkointegrasi apabila variabel-variabel ini memiliki hibungan jangka panjang atau equilibrium. Bila $\varepsilon_{t}$ stasioner berarti $Y_{t}$ dan ${ }^{t}$ berkointegrasi. ${ }^{16}$ Bentuk dasar model kointegrasi.

\section{Engle-Granger}

$$
\Delta \varepsilon_{t}=\delta \varepsilon_{t-1}+\varepsilon_{t}
$$

\section{Augmented Engle-Granger}

$$
\Delta \varepsilon_{t}=\delta \varepsilon_{t-1}+\sum_{i=1}^{k} \alpha_{i} \Delta \varepsilon_{t-1}+\varepsilon_{t}
$$

Hipotesis uji kointeorasi adalah: $\mathrm{H}_{0}: \delta=0$ (tidak berkointegrasi) dengan $\mathrm{H}_{\mathrm{A}}: \delta<0$ (berkointegrasi). Jika t-trace statistic $<t$-McKinnon maka menerima null bypothesis yang artinya tidak berkointegrasi.

\section{c. Uji Kausalitas Granger}

Analisis regresi berurusan dengan ketergantungan sebuah atau lebih variabel terhadap satu atau lebih variabel lain, hasil analisis regresi tidak berimplikasi pada "yang mendatangkan akibat" atau causation. Adanya hubungan antar variabel tidak membuktikan kausalitas atau arah pengaruh. Kausalitas atau arah pengaruh dijustifikasi oleh teori yang dipergunakan bagi pembentukan model. Penelitian dengan analisis regresi, dengan demikian, pada dasarnya bukan upaya untuk mengungkapkan hubungan antar

\footnotetext{
${ }^{16}$ Ibid.
} 
variabel yang secara empirik terjadi di dunia nyata, tetapi upaya untuk menjustifikasi suatu teori. Analisis kausalitas, walaupun implementasinya tetap harus dipandu teori, memiliki keluwesan dalam menentukan arah kausalitas hubungan fungsional antara dua variabel ekonomi. Pada analisis ini, hubungan kausalitas antar dua variabel ekonomi, tidak secara apriori ditentukan oleh teori, tetapi ditentukan oleh hasil analisis uji kausalitas. ${ }^{17}$ Uji Granger akan menyelesaikan persoalan ini dengan merumuskan model dasar regresi kausalitas sebagai berikut.

$$
\begin{aligned}
& Y_{t}=\sum_{i=1}^{m} \alpha_{i} Y_{t-i}+\sum_{j=1}^{m} \beta_{i} X_{t-j}+\varepsilon_{1 t} \\
& X_{t}=\sum_{i=1}^{m} \lambda_{i} X_{t-i}+\sum_{j=1}^{m} \delta_{i} Y_{t-j}+\varepsilon_{2 t}
\end{aligned}
$$

Ada empat kemungkinan kausalitas antara $Y_{t}$ dan $X_{Y_{t}}$ 1) :) Kausalitas satu arah $X_{t}$ mempengaruhi atau menyebabkan , bila $\sum_{j=1}^{m} \beta_{i} \neq 0$ dan 2) $\left.\cdot \sum_{j=1}^{m} \delta_{i}=0\right)$ Kausalitas satu arah $Y_{t}$ mempengaruhi atau menyebabkan $X_{t}$, bila $\sum_{j=1}^{m} \beta_{i}=0$ dan 3) $\left.\sum_{j=1}^{m} \delta_{i} \neq 0\right)$ Kausalitas dua arah $X_{t}$ mempengaruhi atau menyebabkan $Y_{t}$, dan $Y_{t}$ mempengaruhi atau menyebabkan $X_{\Theta}$, bila $\sum_{j=1}^{m} \beta_{i} \neq 0$ dan $X_{t}$ (4) $\sum_{j=1}^{m} \delta_{i} \neq 0$ dan $Y_{t}$ independen satu sama lain, bila $\sum_{j=1}^{m} \beta_{i}=0$ dan $\sum_{j=1}^{m} \delta_{i}=0$. Untuk menjelaskan hubungan dalam variabel penelitian ini, maka model regresi kausalitas sebagai berikut.

Kausalitas Financial Deepening (FD) dan Pertumbuhan Ekonomi (EG)

$$
\begin{aligned}
& F D_{t}=\sum_{i=1}^{m} \alpha_{i} F D_{t-i}+\sum_{j=1}^{m} \beta_{i} E G_{t-j}+\varepsilon_{1 t} \\
& E G_{t}=\sum_{i=1}^{m} \lambda_{i} E G_{t-i}+\sum_{j=1}^{m} \delta_{i} F D_{t-j}+\varepsilon_{2 t}
\end{aligned}
$$

Kausalitas Nilai Tukar Rupiah (EXCR) dan Pertumbuhan Ekonomi (EG)

$$
\begin{aligned}
& E X C R_{t}=\sum_{i=1}^{m} \alpha_{i} E X C R_{t-i}+\sum_{j=1}^{m} \beta_{i} E G_{t-j}+\varepsilon_{1 t} \\
& E G_{t}=\sum_{i=1}^{m} \lambda_{i} E G_{t-i}+\sum_{j=1}^{m} \delta_{i} E X C R_{t-j}+\varepsilon_{2 t}
\end{aligned}
$$




\section{Kausalitas Financial Deepening (FD) dan Nilai Tukar Rupiah (EXCR)}

$$
\begin{aligned}
& F D_{t}=\sum_{i=1}^{m} \alpha_{i} F D_{t-i}+\sum_{j=1}^{m} \beta_{i} E X C R_{t-j}+\varepsilon_{1 t} \\
& E X C R_{t}=\sum_{i=1}^{m} \lambda_{i} E X C R_{t-i}+\sum_{j=1}^{m} \delta_{i} F D_{t-j}+\varepsilon_{2 t}
\end{aligned}
$$

$$
\text { Uji hipotesis } \quad H_{0}: \sum_{j=1}^{m} \iota_{\text {; }} \text { dengan } \quad H_{A}: \sum_{j=1}^{m} \delta \text {. }
$$

Cara pengujian, apabila prob.F statistik $>$ tingkat signifikansi alfa maka menerima null bypothesis.

\section{B. Pembahasan}

Sektor keuangan sangat berperan penting dalam meningkatkan pertumbuhan ekonomi Peran penting yan dimasud berkaitan pembentukan jumlah uang beredar sebagai sumber dana pembangunan. Semakin besar jumlah uang beredar akan mendorong dan meningkatkan penghimpunan dana pembangunan yang bersumber dari sektor keuangan. Selain daripada itu, sektor perbankan yang kompetitif dan berkembang dengan baik mampu berkontribusi dalam pertumbuhan ekonomi.

Tabel 1. juga menyajikan informasi tentang pertumbuhan ekonomi. Pertumbuhan ekonomi tahun 1985 sebesar 2,5 persen dan mengalami peningkatan di tahun 1995 menjadi sebesar 8,2 persen. Pertumbuhan ekonomi setelah krisis di tahun 1997/1998 terus mengalami penurunan yang signifikan, hingga pada tahun 2015 pertumbuhan ekonomi turun menjadi 4,8 persen. Penurunan pertumbuhan ekonomi berbanding lurus dengan melemahnya nilai tukar rupiah terhadap dollar US. Pada tahun 1985, nilai tukar rupiah sebesar 1.1125 rupiah per dollar US dam terus mengalami pelemahan hingga tahun 2015 nilai tukar rupiah sebesar 13.795 rupiah per dollar US.

Tabel 1. Statistik Pendapatan Nasional dan Financial Deepening Tahun 1985-2015

\begin{tabular}{lllll}
\hline \multirow{2}{*}{ Variabel } & Tahun & & \\
\cline { 2 - 4 } & 1985 & 1995 & 2005 & 2015 \\
\hline
\end{tabular}




\begin{tabular}{lllll}
\hline GDP nominal (Rp.Triliun) & 97 & 455 & 2.774 & 11.541 \\
Pertumbuhan Ekonomi (\%) & 2,5 & 8,2 & 5,7 & 4,8 \\
M2 (Rp.Triliun) & 23 & 223 & 1.203 & 4.547 \\
Rasio M2/GDP & 24 & 49 & 43 & 39 \\
Kur* (Rupiah) & 1.125 & 2.308 & 9.830 & 13.795 \\
\hline
\end{tabular}

Keterangan: *End of period

Sumber : Asian Develompent Bank, berbagai tahun

Kenyataan lain, yang ditunjukkan oleh tabel 1, menginformasikan bahwa jumlah uang beredar terus mengalami peningkatan yang signifikan. Pada tahun 1985 jumlah uang beredar sebesar 23 triliun rupiah dan pada tahun 2015 jumlah uang beredar menjadi 4.547 triliun rupiah. Menurunya pertumbuhan ekoomi dan meningkatnya jumlah uang beredar tidak menyebabkan rasio M2/ GDP tinggi. Rasio M2/GDP di Indonesia pada tahun 2015 kurang dari 50 persen. Hal tersebut mencerminkan masih rendahnya tingkat kesehatan sektor keuangan yang berkaitan kemampuan kredit dengan suku bunga kredit dan deposito. Artinya aktivitas sektor ekonomi belum mampu mengahasilkan alokasi yang efisein. Menurut laporan Bank Indonesia (2009), terdapat dua faktor utama yang menyebabkan dangkalnya sektor keuangan Indonesia, yakni (1) rendahnya intermediasi yang dilakukan oleh institusi-institusi di sektor keuangan, dan (2) rendahnya pemanfaatan pasar modal dalam pembiayaan investasi. Terbatasnya kapasitas pembiayaan bank membuat rasio kredit terhadap GDP Indonesia relatif rendah jika dibandingkan dengan negara lain. 
Tabel 2. Uji Stasioneritas

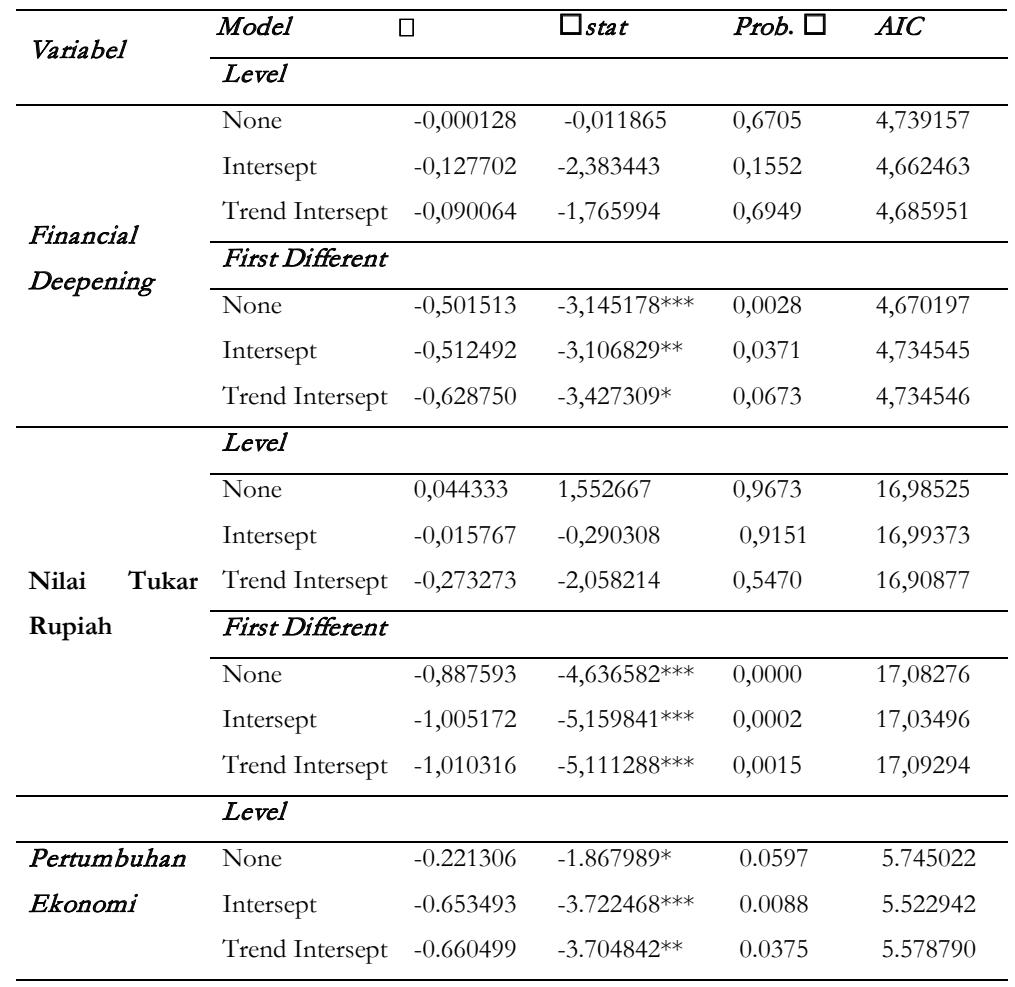

Keterangan: *** Signifikan 1\%; ** Signifikan 5\% dan *Signifikan 10\%; Sumber : Output Eviews8

Model yang stasioner model yang memiliki nilai Akaike information criterion (AIC) minimum dan koefisien $0>$. Variabel financial deepening dan nilai tukar rupiah stasioner stasioner pada model intersept dalam tingkat first different. Variabel pertumbuhan ekonomi stasioner pada model intersept dalam tingkat level. Setelah semua variabel stasioner maka tidak perlu dilakukan uji kointegrasi, karena kointegrasi hanya terjadi di antara variabel-variabel yang tidak stasioner (Tabel 2).

Hasil pengujian kausalitas granger menunjukkan bahwa pertumbuhan ekonomi dan financial deepening memiliki hubungan satu arah, yaitu pertumbuhan ekonomi berpengaruh terhadap 
financial deepening. Setiap ada perubahan pada pertumbuhan ekonomi akan berdampak pada kedalaman sektor keuangan Indonesia. Hasil lain berdasarkan uji kausalitas granger menunjukkan bahwa nilai tukar rupiah tidak menyebabkan pertumbuhan ekonomi dan financial deepening dan pertumbuhan ekonomi di Indonesia (Tabel 3).

Tabel 3. Uji Kausalitas Granger

\begin{tabular}{lcl}
\hline Null Hypothesis: & F-Statistic & Prob. \\
\hline DFD does not Granger Cause DEXCR & 1,29494 & 0,3036 \\
DEXCR does not Granger Cause DFD & 2,03260 & 0,1417 \\
EG does not Granger Cause DEXCR & 2,09012 & 0,1337 \\
DEXCR does not Granger Cause EG & 1,73838 & 0,1914 \\
EG does not Granger Cause DFD & 3,61286 & $0,0311^{* *}$ \\
DFD does not Granger Cause EG & 0,81323 & 0,5015 \\
\hline
\end{tabular}

Keterangan: *** Signifikan 1\%; ** Signifikan 5\% dan *Signifikan 10\%; Sumber : Output Eviews8

Menurut Robinson (dalam Aye, 2015) menerangkan bahwa hipotesis supply-leading adalah lembaga keuangan yang berfungsi dengan baik dapat meningkatkan efisiensi ekonomi secara keseluruhan, menciptakan dan memperluas likuiditas, memobilisasi tabungan, meningkatkan akumulasi modal, mentransfer sumber daya dari sektor tradisional (non-pertumbuhan) guna merangasang pertumbuhan sektor modern lainnya, dan juga mempromosikan kompeten tanggapan pengusaha di sektor ekonomi modern. Banyak literatur menyampaikan bahwa pengembangan keuangan penting untuk pertumbuhan. Hasil penelitian yang dilakukan oleh Marashdeh (2014) mengenai hubungan antara financial deepening dan pertumbuhan ekonomi di Arab Saudi. Hasil penelitianya mendukung hipotesis supply-leading, dimana financial deepening dapat memacu pertumbuhan ekonomi.

Hasil dalam penelitian ini menunjukkan hasil yang sama yang dilakukan oleh Yildiz (2015) tentang hubungan antara financial 
deepening dan pertumbuhan ekonomi di Turki. Dalam hasil penelitian ini mendukung hipotesis demand-pulling. Hipotesis Demand-following menjelaskan bahwa Pertumbuhan ekonomi merupakan faktor penyebab untuk pengembangan sektor keuangan.

Perlunya investasi produktif yang akan meningkatkan sektor-sektor produktif sehingga mampu berkontribusi tinggi dalam pertumbuhan ekonomi. pertumbuhan ekonomi meningkatkan permintaan untuk instrumen keuangan yang modern sehingga pada gilirannya akan menyebabkan pertumbuhan di sektor keuangan. Disisi lain, pendapatan merupakan insentif yang diperoleh masyarakat dari kegiatan usahanya. Dalam kegiatan ekonomi, meningkatnya insentif yang diterima masyarakat merupakan akibat dari semakin tingginya pendapatan. Pendapatan yang tinggi pada akhirnya berdampak pada semakin tinggi permintaan terhadap barang dan jasa dalam perekonomian. Secara makro ekonomi, pendapatan dapat diartikan sebagai keseluruhan barang dan jasa (output) yang dihasilkan oleh perekonomian suatu negara pada suatu periode waktu tertentu. Tingginya pendapatan mengisyaratkan bahwa adanya peningkatan output yang dihasilkan oleh perekonomian. Secara umum semakin tinggi pendapatan masyarakat, maka akan semekain meningkatkan financial deepening.

Sedangkan penyebab sektor keuangan tidak berdampak pada pertumbuhan ekonomi diakibatkan karena masih dangkalnya sektor keuangan di Indonesia yang ditunjukan rasio jumlah uang beredar terhadap pendapatan nasional. Hal tersebut didukung dengan laporan Bank Indonesia, dimana rasio jumlah uang beredar terhadap pendapatan nasional (M2/GDP) kurang dari 40 persen. Artinya sektor keuangan di Indonesia kurang sehat dan belum mampu menghasilkan alokasi yang efisien pada sektor ekonomi.

Hasil lain berdasarkan uji kausalitas granger menunjukkan bahwa nilai tukar rupiah tidak menyebabkan pertumbuhan ekonomi dan financial deepening dan pertumbuhan ekonomi di Indonesia Studi empiris yang sama pernah dilakukan oleh Ruslan (2011) yang menganalisis financial deepening terhadap perekonomian 
Indonesia. Hasil penelitian menunjukkan bahwa nilai tukar tidak berpengaruh signifikan financial deepening. Pergerakan nilai tukar (kurs) di Indonesia bersifat flexible exchange rate. Kekuatan permintaan dan penawaran dari pelaku keuangan di pasar uang sangat menentukan. Pasar uang dan sektor perbankan tidak saling berhubungan, karena perbedaan persepsi masyarakat. Persepsi masyarakat di pasar uang lebih condong pada profit yang besar dengan adanya resiko fluktuasi nilai kurs mata uang, sedangakan perilaku masyarakat di sektor perbankan lebih didasarkan pada perkiraan jangka panjang dalam investasi dengan mengutamakan aspek keamanan dananya.

\section{Simpulan}

Dari pembahasan deskripsi dan interpretasi ekonomi sebelumnya dapat ditarik beberapa kesimpulan. Pertama, adanya gejolak perekonomian dalam negeri maupun global akan berdampak pada sektor keuangan dan pertumbuhan ekonomi di Indonesia. Kedua, sektor keuangan di Indonesia masih dangkal (shallow) yang tercermin dari rasio jumlah uang beredar terhadap produk domestik bruto. Ketiga, berdasarkan uji kausalitas granger menunjukkan bahwa financial deepening dan pertumbuhan ekonomi memiliki hubungan satu arah, yaitu pertumbuhan ekonomi mempengaruhi financial deepening. Artinya, berlakunya Hipotesis Demand-following menjelaskan bahwa Pertumbuhan ekonomi merupakan faktor penyebab untuk pengembangan sektor keuangan. Nilai tukar rupiah dan financial deepening tidak saling mempengaruhi, serta pertumbuhan ekonomi dan nilai tukar rupiah tidak saling mempengaruhi.

Pentingnya peranan pemangku kebijakan moneter (Bank Sentral) dan Otoritas Jasa Keuangan untuk berkoordinasi dengan Pemerintah dalam peningkatan dan pengembangan sektor keuangan sehingga mampu memacu pertumbuhan ekonomi di Indonesia. Melalui sektor perbankan, meningkatkan penyaluran kredit produktif dan investasi produktif untuk merangsang sektor- 
sektor produktif sehingga mampu mendorong pertumbuhan ekonomi. Melalui pasar keuangan yang dalam dapat mendorong lebih banyak investor untuk menanamkan dananya di pasar keuangan sehingga dapat berdampak positif terhadap pembiayaan ekonomi. Hal ini dapat dilakukan dengan memperkaya instrumen investasi, seperti instrumen berjangka panjang. Memperdalam pasar keuangan juga dapat dilakukan sebagai upaya untuk menarik ekses likuiditas di perekonomian dan memperkecil risiko gangguan terhadap stabilitas sistem keuangan yang berasal dari gejolak nilai tukar maupun fluktuasi di pasar saham atau obligasi. Namun, untuk meminimalisir dampak negatif pendalaman pasar keuangan, perlu diikuti oleh perangkat peraturan untuk institusi keuangan. 


\section{DAFTAR PUSTAKA}

Asian Development Bank. (Various years). Key Indicators for Asia and the Pacific. Dipetik Januari 2017, 14, dari https://www. adb.org/publications/series/key-indicators-for-asia-andthe-pacific.

Aulia. M. D, "Analisis Efektivitas Penggunaan Cadangan Devisa dan Financial Deepening Terhadap Stabilitas Nilai Tukar", Jurnal Ekonomi dan Kebijakan Publik, Vol. 3 No. 2, 2016.

Aye, G. C, "Causality between Financial Deepening and Economic Growth in Negeria: Evidence form a Bootstrap Rolling Window Approach", Journal of Economic, Business and Management, Vol. 3, No.8, 2015.

Bank Indonesia, Laporan Perekonomian Indonesia, (2009), Dipetik Mei 14, 2018, dari http://www.bi.go.id/id/publikasi/ laporantahunan/perekonomian/Pages/lpi_09.aspx

Ghildiyal, V. A, "Impact of Financial Deepening on Economic Growth in Indian Perspective: ADRL bound Testing Appoac to Cointegration", Asian Economic and Social Society, Vol 3. No. 3, 2015.

Gujarati, N. D, Basic Econometrics (4rd Edition ed.). New York: McGraw-Hill, 2004

Marashdeh, H. A.-A.-M. (2014), Financial Deepening and Economic Growth in Saudi Arabia. Journal of Emerging Market Finance, 13(2)

Ndebbio, J, "Financial Deepening, Economic Growth and Development: Evidence from Selected Sub-Saharan African Countries", African Economic Research Consortium, Research Paper Vol. 142, Agustus 2004.

Ohwofasa, B. O.-C, Financial Deepening and Economic Growth in Nigeria, 1986-2011: An Empirical Investigation. Vol 1, No. 1, 2013. 
Onwumere, J, "The Impact of Financial Deepening on Economic Growth: Evidence form Nigeria", Research Journal of Finance and Accounting, Vol. 3 No. 10. 2012.

Pradhan, R. P, "Financial Deepening, Foreign Direct Investment and Economic Growth: Are They Cointegerated", International Journal of Financial Research, Vol. 1, No. 1, 2010.

Pulungan, A. M, "Perkembangan Perbankan dan Problem Intermediasi", Jurnal Keuangan dan Perbankan, Vol. 16, No. 2, 2012.

Ruslan. D, "Analisis Financial Deepening di Indonesia", Journal of Indonesian Applied Economics, Vol. 5 No. 2, 2011. 